\title{
Before Memex: Robert Hooke, John Locke, and Vannevar Bush on External Memory
}

\section{Richard Yeo}

Centre for Public Culture and Ideas, Faculty of Arts, Griffith University, Brisbane, Australia

\section{Argument}

In 1945 Vannevar Bush proposed a machine that acted as a "supplement" to memory and met the particular information needs of its user. Because this "memex" recorded "trails" of selected documents, it has been seen as a precursor to hypertext. However, this paper considers Bush in relation to earlier concerns about memory and information, via the ideas of Robert Hooke and John Locke. Whereas Bush modeled the memex on the associative processes of natural memory, Hooke and Locke concluded that an external archive had to allow collective reason to overcome the limits of individual memory, including its tendency to freeze and repeat patterns of ideas. Moreover, they envisaged an institutional archive rather than one controlled by the interests and mental associations of an individual. From this early modern perspective, Bush's memex appears as a personal device for managing information that incorporates assumptions inimical to the strategies required for scientific analysis.

In the Atlantic Monthly of July 1945, Vannevar Bush, engineer and wartime science advisor, imagined a microfilm machine that stored and retrieved vast amounts of information:

Consider a future device for individual use, which is a sort of mechanized private file and library. It needs a name, and, to coin one at random, "memex" will do. A memex is a device in which an individual stores all his books, records, and communications, and which is mechanized so that it may be consulted with exceeding speed and flexibility. It is an enlarged intimate supplement to his memory. (Bush 1945, 106-7; reprinted in Bush 1946a, 16-38) ${ }^{1}$

Bush explained that books and documents of various kinds were to be stored and compressed on microfilm: "Only a small part of the interior of the memex is devoted to storage, the rest to mechanism. Yet if the user inserted 5000 pages of material a day it would take him hundreds of years to fill the repository" (Bush 1945, 107). On this principle, "The Encyclopaedia Britannica could be reduced to the volume of a matchbox.

\footnotetext{
${ }^{1}$ For biographical details, see Zachary 1997.
} 


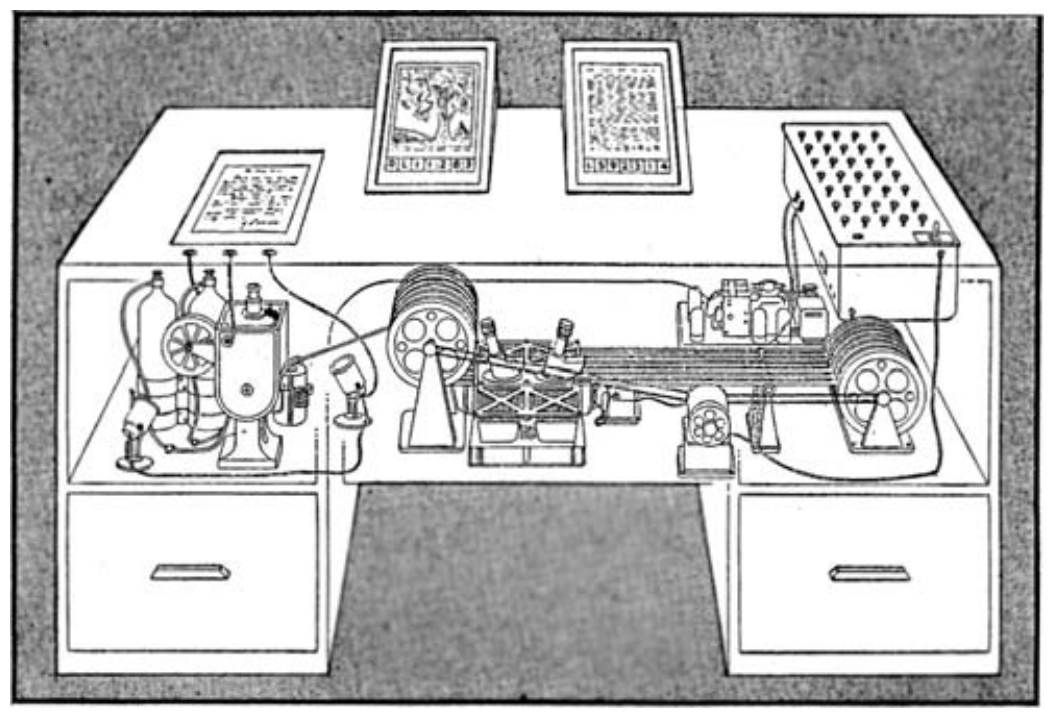

Fig. 1. "Memex" from Life, 10 September 1945, p. 123.

A library of a million volumes could be compressed into one end of a desk" (ibid., 103). ${ }^{2}$ Items from the archive were to be selected and located by rapid scanning far exceeding the "few hundred a minute" punched-card searching. Bush expected that "the use of photocells and microfilm" would yield a "rate of a thousand a second" (ibid., 105-6). ${ }^{3}$ He did not consider any of the above as significant innovations; in technical terms, the memex was merely "the projection forward of present-day mechanisms and gadgetry" (ibid., 107) (fig. 1).

Bush regarded the notion of "associative indexing" as his key conceptual contribution. As he explained, this was "a provision whereby any item may be caused at will to select immediately and automatically another. This is the essential feature of the memex. The process of tying two items together is the important thing." This "linking" (as we now say) constituted a "trail" of documents that could be named, coded, and found again. Moreover, after the original two items were coupled, "numerous items" could be "joined together to form a trail"; they could be "reviewed in turn, rapidly or slowly, by deflecting a lever like that used for turning the pages of a book. It is exactly as though the physical items had been gathered together from widely separated sources and bound together to form a new book" (ibid.). ${ }^{4}$ The user of a memex could create

\footnotetext{
${ }^{2}$ Bush gave the current reduction factor in microfilming as 20 , but assumed "a linear ratio of 100 for future use" (ibid., 103).

${ }^{3}$ These were the punched cards invented by Herman Höllerith. The memex was never built.

${ }^{4}$ The example Bush gives is a quest to find information on the relative merits of the Turkish short bow and the English long bow in the crusades (ibid., 107).
} 


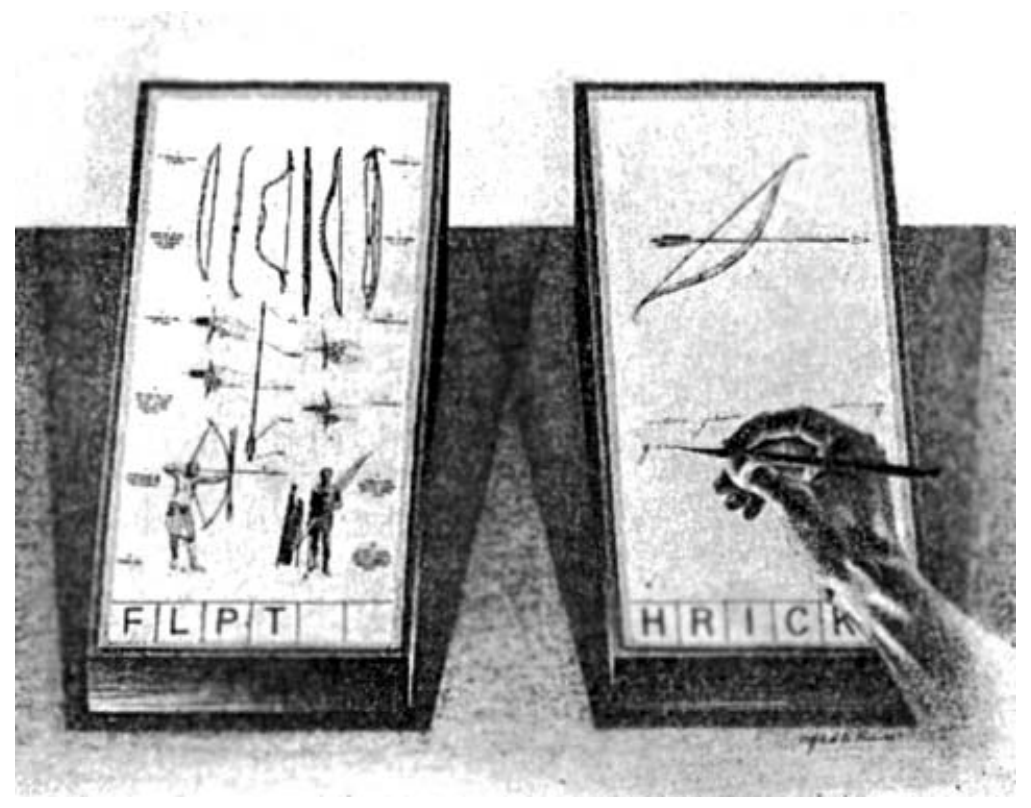

Fig. 2. "Memex in Use" from Life, 10 September 1945, p. 124.

personally-selected compilations of information: "Wholly new forms of encyclopedias will appear, ready-made with a mesh of associative trails running through them, ready to be dropped into the memex and there amplified" (ibid., 108) ${ }^{5}$ (fig. 2).

The title of this oft-cited article invites us to imagine how we may think, not how we might remember. Bush calls the memex a "device," a "mechanized private file," rather than a machine; but it takes its place in a system comprised of other machines. He refers to the visions of Gottfried Wilhelm Leibniz and Charles Babbage and a future in which machines do routine mathematical calculations, thus leaving the mind free for more creative tasks (Bush 1945, 102, 104). ${ }^{6}$ He predicts a machine capable of handling "formal logic": "We may some day click off arguments on a machine with the same assurance that we now enter sales on a cash register" (Bush 1945, 105). The memex was not this kind of machine, but Time leapt to the conclusion that Bush "predicts a brain robot that will relieve man of much of the routine spadework of thinking... store facts for ready recall, sort a man's ideas, even organize them logically" (Anon.

\footnotetext{
${ }^{5}$ The prospect of encyclopaedias on microfilm also appealed to H. G. Wells (see Wells [1938] 1994, 60-63, 86-87). For earlier dreams of condensing knowledge, see Yeo 2001.

${ }^{6}$ Bush does not seem to mean Leibniz's quest for "characteristica," or essential notions, to which signs could be assigned and then manipulated in a combinatorial system. This did have links with the art of memory, as I discuss below (see Yates 1966, 365-69; Rossi 2000, chap. 8; for Bush's "invention" of a differential analyzer, see Zachary 1997, 49-53, 73-79).
} 
1945a, 41). ${ }^{7}$ Bush did not conflate these functions, but he did see the memex as facilitating more effective thinking by responding to information overload. The latter was a restraint on innovative thought: "There is a growing mountain of research. But there is increased evidence that we are being bogged down today as specialization extends. The investigator is staggered by the findings and conclusion of thousands of other workers - conclusions which he cannot find time to grasp, much less to remember" (Bush 1945, 101). ${ }^{8}$ Bush characterized selection and manipulation of datain both the sciences and the humanities - as "repetitive processes of thought" that were best "relegated to the machines" (ibid., 104). By proposing the memex in an article liberally sprinkled with various mechanical supplements to thought and communication, Bush identified the concept of externalized memory with an integrated system of technical devices that interact with the brain of the user.'

In his Cybernetics (1948), Norbert Wiener, a colleague of Bush at MIT, did not refer to the memex, but its status is easily handled by his dictum that "information is information, not matter or energy" (Wiener [1948] 1973, 132; also 11-12 for his coining the term "cybernetics" from the Greek kuberne, steersman). On this view, a blind man's cane is part of the cybernetic system that includes the cane, his mind, and his body. In Natural-Born Cyborgs, Andy Clark elaborates on this by affirming that a cyborg mind need not sport electro-chemical implants; rather, the brain can have systemic dependence on, and interaction with, various kinds of external storage devices (Clark 2003; see also Clark and Chalmers 1998). ${ }^{10}$ This "extended mind" hypothesis contends that cognitive processes extend into the world when we use tools of various kinds; that our brains employ stable features of the physical environment to freeze thoughts, as in images on stone or canvas, writing on paper, or as files in a computer. ${ }^{11}$ As one of these external aids, the memex offered two kinds of help: first, it stored data in stable and accessible form; second, and more significantly for Bush, it captured creative associative links made by the brain or recalled from memory - in "trails [that] do not fade" (Bush 1945, 107). These associative trails have been seen

\footnotetext{
${ }^{7}$ Life magazine carried a version of Bush's article, with illustrations, including a summary of "What Dr. Bush foresees," including "A Thinking machine: A development of the mathematical calculator. Give it premises and it would pass out conclusions, all in accordance with logic" (Anon. 1945b, 113).

${ }^{8}$ Bush mentioned this issue in an article of 1933 (see Bush [1933] 1946b, 9-10).

${ }^{9}$ In one of his last published definitions, Bush did use the term "machine": "the idea of a machine that should be an extension of the personal memory and body of knowledge belonging to an individual" (Bush 1970, 190).

${ }^{10}$ Cyborg, a portmanteau of "cybernetic organism." For its coinage, see Clynes and Kline 1960. There is an earlier use of it in the New York Times, 22 May 1960. Both are cited in the Oxford English Dictionary, 2nd edn. (more generally, see Pickering 1995; Hayles 1999).

11 The background here includes Karl Lashley's coinage of "engram" to denote a single entry in the biological memory system. The partner of this term in more recent cognitive psychology is "exogram" - namely, an external prompt, such as a rhyme, diagram, or notebook. Exograms embody memories and combine with the distributed "engrams" in the brain (see Lashley 1960; Donald 1991, 308-333; Menary 2006).
} 
as the anticipation of electronic hypertext. ${ }^{12}$ Consequently, Bush's ideas are usually approached as foundational or prophetic, with discussion turning on the extent to which he anticipated later developments. ${ }^{13}$

Rather than viewing Bush as a precursor of what followed in the digital age, I want to look back, to situate him in the long tradition of speculation about ways of assisting natural memory. G. Pascal Zachary declares that "Bush took his place in the grand tradition of what historian Frances Yates called 'the art of memory.' His memex, in this context, was a modern-day 'memory theater"' (Zachary 1997, 262). As a suggestive remark in a biography, this statement is acceptable; but as intellectual history it requires considerable qualification and explanation. What were the principal features of the classical art of memory? There were two main components. The key surviving text from the classical period, Ad Herennium, referred to these as background or places (loci) and images (imagines). ${ }^{14}$ The practitioner imagined a structure of some kind, such as a palace with several rooms, and took care to furnish it with clearly marked places, such as "an intercolumnar space, a recess, an arch, or the like." These places had to be memorized as an ordered series, thus forming a familiar, permanent mental background. In the next stage, specially chosen vivid images (imagines agentes) were deposited in these places as reminders of the things or speeches or arguments to be recalled. When one walked mentally through this imagined space in a strict sequence, the images in each of the places gave up their associated content. A crucial additional point is that the choice of images was an individual affair: as the author explained, an image "that is well-defined to us appears relatively inconspicuous to others. Everybody, therefore, should in equipping himself with images suit his own convenience" (Anon. 1954, Book III, 207-25, 233). ${ }^{15}$ Thus the art of memory itself imposed a load on memory: it involved the double task of remembering the stable background (usually a shared one based on common physical structures) and a personal set of mental associations between images and content. The payoff was that this background could be internalized as mental scaffolding or wallpaper; it could then function as a virtual externalized prompt for the recollection of names, quotations or arguments (see Sutton 2002, 136-7; for a detailed account, see Carruthers 1990).

If we tune into conversations in mid sixteenth-century Europe, we hear the art of memory being disparaged. Agrippa waited until the last chapter of his cautionary

\footnotetext{
12 See, for example, Landow 1992, 14-18; Kitzmann 2001. For disavowal of the hyperbole in some of this literature, see Kendrick 2001.

${ }^{13}$ But see Buckland 1992 for his immediate precursors. For a valuable collection of sources and commentary, see Nyce and Kahn 1991.

${ }^{14}$ This anonymous work dates from about 86-82 BC. The title indicates that it is addressed to Gaius Herennius. This text was contemporary with the works of Cicero and mistakenly attributed to him in the thirteenth century. Another influential Latin work is Quintilian's Institutio Oratoria (end of the first century AD), although his support of the technique was somewhat muted (see Yates 1966, 35).

${ }^{15}$ For an account of a person who used a similar technique, apparently without prior knowledge of the ancient art, see Luria 1975. On visual encoding as the key feature, see Schacter 1996, 46-8.
} 
account of the arts and sciences to debunk it. His point was that artificial memory techniques depended on the foundation supplied by natural memory, which itself might be cluttered by the required stock of places and images:

It [artificial memory] cannot stande without natural Memorie, whiche oftentimes is dulled with monstrouse Images, that oftentimes it causeth madnesse, and fresie in steede of profounde and sure Memories, to wite, whilest that it burdeninge the natural Memories with the Images of infinite things, and wordes, causeth them to become madde with Arte, that abide not content with the limittes of nature. (Agrippa [1531] 1569, 24-5) ${ }^{16}$

By at least the early seventeenth century, the reputation of topical, or place, memory had substantially faded, although its emphasis on the importance of order remained influential. ${ }^{17}$ The notion of places (topoi or loci) as described in the art of memory is a plausible ancestor of the concept of "common places" (loci communes) of rhetoric, as taught by Cicero and Quintilian (Sorabji 1972, 29-31). ${ }^{18}$ By the Renaissance, these commonplaces were increasingly interpreted as collections of quotations from the major classical texts entered in a commonplace book under thematic Heads. From the 1500 s, this practice of commonplacing became the central pedagogic framework of Western education (Moss 1996; Goyet 1996). ${ }^{19}$ Advocated by leading humanists such as Agricola, Erasmus, Melanchthon, and Vives, who largely rejected classical mnemonic rules, such notebooks were seen as ways of training a capacious memory; they were prompts to recollection, not substitutes for it.

Bush was thus the inheritor of a set of intellectual conditions that allowed him to make assumptions not so easily available to those in classical, or even early modern, times. Take, for example, this comment:

[Man] has built a civilization so complex that he needs to mechanize his records more fully if he is to push his experiment to its logical conclusion and not merely become bogged down part way there by overtaxing his limited memory. His excursions may be more enjoyable if he can reacquire the privilege of forgetting the manifold things he does not need to have immediately at hand, with some assurance that he can find them again if they prove important. (Bush 1945, 108; emphasis added)

Bush enjoyed the benefits of print culture - not only the legacy of techniques for note taking but also the existence of public libraries, catalogs, and archives. He could retrieve

\footnotetext{
16 The original Latin version was De Incertitudine et Vanitate Scientiarum et Artium (Paris, 1531).

${ }^{17}$ Of course, manuals on memory arts continued to appear, as they still do today.

${ }^{18}$ Erasmus stressed ordering, but shared Quintilian's reservations about the visual images used in mnemonic arts (Yates 1966, 133-4, 313).

${ }^{19}$ The legacy of this practice is manifest in Bush's own suggestion that users of the memex annotate and crossreference the texts they store on microfilm: "As he has several projection positions, he can leave one item in position while he calls up another. He can add marginal notes and comments... Thus he builds a trail of his interest through the maze of materials available to him" (Bush 1945, 107).
} 
information from external deposits rather than needing to recall it from memory. Why, then, describe the memex as "an enlarged intimate supplement" to memory - as if books, journals, and notebooks were not similar aids? One likely reason is that he conceived the memex not only as an external store of information drawn from various sources, but as a preserver of the user's own mental associations between various pieces of information, between "trails" of document searches that served as an external record of trains of thought. In this respect, Bush emphasized the individualistic element in the art of memory, the idiosyncratic associations that prompted recall for each person. Significantly, he also denigrated, at least by implication, the other component of the classical art - the value of a stable background framework, such as agreed subject classifications. If the memex is a modern memory theater, it is one in which little of the public features of the theater remain.

In this article, I want to bring the inventor of the memex into confrontation with Robert Hooke (1635-1703) and John Locke (1632-1704). ${ }^{20}$ These two avid collectors of information might well have embraced such a device. Like Bush, they were concerned about information overload and the desirability of efficient methods of storing and finding data. Of course, the theological and philosophical contexts in which these three individuals worked were very different; and there is a risk of anachronism in comparing them. Nevertheless, I think it is worth viewing Hooke and Locke as working towards "the privilege of forgetting" - a notion that, unlike Bush, they could not take for granted. Both seventeenth-century figures commented on the principles and practices of note taking. Hooke did so in a long piece entitled "A General Scheme, or Idea of the Present State of Natural Philosophy," probably written in 1666, but only published in his Posthumous Works, edited by Richard Waller (1705). ${ }^{21}$ Locke did this in his first mature appearance in print: "A New Method of a CommonPlace-Book," published in the Bibliothèque Universelle of 1686, and later in English in his Posthumous Works (1706). During the Renaissance commonplace books were primarily conceived as prompts for what should be memorized; by the seventeenth century, they came to be regarded as containers in which information is stored for later retrieval. ${ }^{22}$ Breaking with the rhetorical purpose of commonplaces, Locke and Hooke began to think in terms of retrieval from external sources, rather than recall from memory.

By considering these three thinkers together, some significant, perhaps unexpected, contrasts emerge. Hooke and Locke worked towards the importance of externalized

\footnotetext{
${ }^{20}$ Hooke and Locke shadowed each other throughout their lives, from their time together at Westminster School, London, then Christ Church, Oxford, where Hooke was a choral student and Locke studied for a Bachelor of Arts, and subsequently held a "Studentship" (or fellowship) and various teaching posts. Finally, they were fellows of the Royal Society of London: Hooke was elected in June 1663; Locke in November 1668. For their common early education, see Smith 2006.

21 Of course, Hooke kept a diary (see Hooke 1968; Mulligan 1996).

${ }^{22}$ For methods of note taking in this period, see Blair 2004; Malcolm 2004; Yeo 2004. For a comment, see Daston 2004.
} 
memory after an examination of novel ways of getting information into the mind and retaining it in memory; these included mechanical (and other) enhancements. They discerned two seemingly opposed features of natural memory: the well-known tendency to forget, but also the rigidity of the patterns, both temporal and associative, by which it did store and recall ideas. They diagnosed these patterns as obstacles to rational and scientific inquiry and stressed the need to reclassify and compare data collected in collaborative Baconian projects. Some 250 years later, Bush was able to assume the notion of externalized memory without argument and to take advantage of far more powerful techniques for storing and searching information. However, he conceived the memex as a device for fixing the associative patterns of natural memory. As he wrote: "One cannot hope thus to equal the speed and flexibility with which the mind follows an associative trail, but it should be possible to beat the mind decisively in regard to the permanence and clarity of the items resurrected from storage" (Bush 1945, 106). It is, therefore, the two early modern authors who moved more radically away from natural memory as the basis of information management. Hooke and Locke accepted the importance of external memory after exploring, and rejecting, the possibility of augmented natural memory, whereas Bush modeled the search strategies of his memex on the associative processes of natural memory.

I pursue this set of comparisons and contrasts in the following sections. I follow Hooke and Locke on their path toward acknowledgment of the inadequacies of natural memory, its possible improvement, and the need for external archives. I identify some disagreement between them by discussing parts of Locke's Essay Concerning Human Understanding (1690) as a response to Hooke's Micrographia (1665). I then analyze the early modern authors' privileging of reason and judgment over memory. Whereas Locke believed that personal note taking was the best insurance against a poor memory, Hooke sought to apply some of the lessons of the art of memory to the task of managing information gathered in collective Baconian research. He stressed the importance of shared, but revisable, categories that allowed reason to analyze and reorganize data in an institutional archive. In this way, he hoped, the community of researchers could overcome the limits of individual memory, one of which was the repetitive character of its links between ideas. Finally, I return to Bush, arguing that some crucial assumptions in his writings about memex are more sharply delineated when compared with those of Hooke. Whereas Bush's memex was a personal device anchored to an individual memory, Hooke imagined an external repository that might function as an institutional memory.

\section{Robert Hooke: Enhancing the Senses and Memory}

Bush again provides a vivid entry point. He predicted the arrival of photographic devices, worn by an observer, which immediately transferred to film anything chosen for recording: 


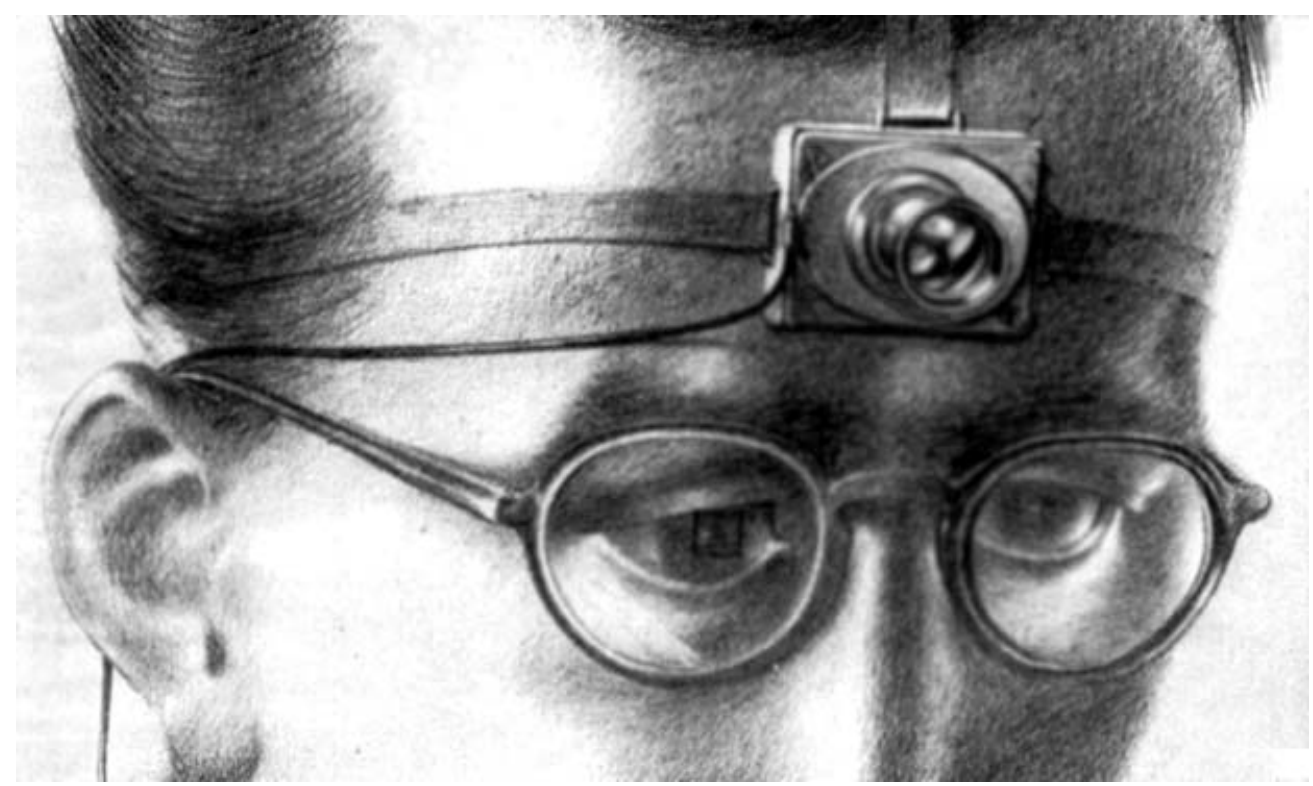

Fig. 3. "A Scientist of the Future" from Life, 10 September 1945, p. 112.

The camera hound of the future wears on his forehead a lump a little larger than a walnut.... On a pair of ordinary glasses is a square of fine lines near the top of one lens, where it is out of the way of ordinary vision. When an object appears in that square, it is lined up for its picture. As the scientist of the future moves about the laboratory or the field, every time he looks at something worthy of the record, he trips the shutter and in it goes, without even an audible click. (Bush 1945, 102) (fig. 3)

This camera headgear would have appealed to Robert Hooke, master of contraptions and gadgets, "London's Leonardo" (Inwood 2002; Bennett et al. 2003). It might well have enabled him to draw with greater ease his images of magnified fleas, spores, insects, stinging nettles, and human hairs.

Hooke began his Micrographia by declaring that it was the privilege and duty of mankind to understand nature. He then immediately stressed the weaknesses of man's senses, a condition brought about both by "corruption, innate and born with him," and also by negligence and disregard of those precepts available in the Scriptures (Hooke 1665, "Preface," sig. a1r). This is an allusion to the effects of Original Sin. It was a standard tenet of both Catholic and Protestant theology that Adam and Eve were endowed with perfect senses. As Martin Luther declared of Adam: he could "see objects a hundred miles off better than we can see them at half a mile, and so in proportion with all the other senses" (cited in Harrison 2002, 242; also Harrison 1998, 211-22). Due to the Fall, however, Adam's progeny had inherited a corrupted set of faculties. In Protestant England, there was a hopeful interpretation of this postlapsarian condition, 
albeit one premised on the acknowledgment of impaired faculties. As Joseph Glanvill put it, "Adam needed no Spectacles. The acuteness of his natural Opticks ... shew'd him much of the Coelestial magnificence... without a Galileo's tube" (Glanvill 1661, 5; a revised version appeared as Scepsis Scientifica in 1665). However, members of the Royal Society promoted Francis Bacon's view that in man's state of probation on Earth, God's command to work and seek Redemption included the duty to understand and control Nature, thus producing some improvements to the human condition. In this way, an acceptance of the effects of the Fall could be turned into a positive scientific endeavor to attain a partial restoration of prelapsarian knowledge.

With Glanvill and others in the Royal Society, Hooke urged enlarging "the dominion, of the Senses" so as to "recover some degree of those former perfections," thus "rectifying the operations of the Sense, the Memory, and Reason." He imagined extensions to natural capacities that conjure up a cyborg future: "The next care to be taken, in respect of the Senses, is a supplying of their infirmities with Instruments, and, as it were, the adding of artificial Organs to the natural" (Hooke 1665, "Preface," sig. $\mathrm{a} 1 \mathrm{r}$ and $\mathrm{a} 2 \mathrm{r}$ and $\mathrm{v}$; emphasis in original). ${ }^{23}$ There was a more general rationale for this, as he explained in the opening lines of the Micrographia:

It is the great prerogative of Mankind above other Creatures, that we are not only able to behold the works of Nature, ... but we have also the power of considering, comparing, altering, assisting, and improving them to various uses... By the addition of such artificial Instruments and methods, there may be, in some manner, a reparation made for the mischiefs, and imperfection, mankind has drawn upon it self... whereby every man, both from a deriv'd corruption, innate and born with him, and from his breeding and converse with men, is very subject to slip into all sorts of errors. (Hooke 1665, "Preface," sig. a1r)

Just as telescopes and microscopes extended vision, Hooke expected that similar improvements could be made for hearing, and also for memory. But what are these artificial memory aids? What was the equivalent of spectacles, the microscope, telescope, or the ear-trumpet? One obvious answer must be the classical mnemonic techniques; but Hooke did not pursue this option in the Micrographia. ${ }^{24}$ What did attract him was self-experimentation in search of ways to extend his own senses and mental faculties. As we know from his diary, Hooke regularly subjected his body to various chemicals and medicines, and so it is not surprising that he looked in this direction for a way of improving memory. In the entry for 11 September 1677, he writes:

Mr. Melancholy told me that a freind of his had been recoverd of a bad memory and severall other distempers by carrying a small box full of very fine filings of the best refined silver and now and then licking of it with his finger and swallowing it. It seems

${ }^{23}$ On Hooke's approach to the problem of writing about visual evidence, see Harwood 1989; Dennis 1989.

${ }^{24}$ Hooke did not discuss classical "topical" memory techniques; however, he was interested in the mnemonic features of artificial languages. I return to this below. 
very probable that this may be a very efficatious medicine, as is steel... and the other medicines and minerals, of this query further. (Hooke 1968, 311-12; for the full range of self-experimentation, see Mulligan 1996; Jardine 2003)

Hooke realized that memory posed special issues. Whereas various instruments, or drugs, might magnify the input of each of the five senses, the role of memory is to retain information from all the senses. In the much-cited Book X of the Confessions, Saint Augustine outlined his conception of memory as "awe-inspiring," its "vast cloisters" unfathomable, mysteriously outreaching the capacities of the human mind in which it seemingly resides (Augustine 1961, Book 10; also Coleman 1992, chap. 6). In contrast, Hooke regarded memory as a far more humble faculty, both unreliable in retaining ideas and also prone to preserve useless "things" rather than the information that "Reason" requires. He spelt this out in a passage following the discussion of the weaknesses of the senses:

The like frailties are to be found in the Memory; we often let many things slip away from us, which deserve to be retain'd; and of those which we treasure up, a great part is either frivolous or false; and if good, and substantial, either in tract of time obliterated, or at best so overwhelmed and buried under more frothy notions, that when there is need of them, they are in vain sought for. (Hooke 1665, "Preface," sig. a1v)

Hooke was preoccupied with the load on memory, as indicated in one of his "Lectures of Light" presented as part of the Cutlerian lectures. In the lecture delivered on 21 June 1682, he advanced a physical account of memory, treating it as a material organ having "its Situation somewhere near the Place where the Nerves from the other Senses concur and meet." Memory was a "Repository of Ideas." Hooke regarded these "Ideas" as corporeal, but he kept a role for the "Soul" as the agent of "Attention" that received impressions from the senses, formed ideas, and renewed them by a kind of "Radiation" akin to the action of the Sun (Hooke 1705b, 138-48; Singer 1976; Richards 1992, 67-9; Draaisma 2000, 53-8). ${ }^{25}$

Having envisaged the memory and the ideas it held as material, Hooke confronted the fact that the capacity of memory was necessarily constrained by the volume of the brain that housed it. He did not flinch. Calculating the number of "Ideas" stored in the memory of an average person over a year, deducting time asleep, when no Ideas are registered, he concluded that we add to this "Store" by "about one Million of Ideas" each year. This figure frightened him and he settled on "one hundred for every Day," so that a person would gather almost two million ideas over fifty years (Hooke 1705b, 143). His microscopic observations inspired the confident assurance that "we shall not need to fear any Impossibility to find out room in the Brain" for even more.

\footnotetext{
${ }^{25}$ For primary documents and commentary, see Oldroyd 1980, 17-32. I return to some of the details of Hooke's account below.
} 
We only had to consider "in how small a bulk of Body there may be as many distinct living Creatures as here are supposed Ideas" (Hooke 1705b, 143-44). Yet for Hooke any amazement at the capacity of memory was accompanied by awareness of its finite limits. We might also infer that if the senses were improved as Hooke contemplated, they would take in more impressions from the world, thus creating more ideas. In other words, more acute senses would exacerbate the burden on memory.

Hooke seems to have arrived at this conclusion, and he looked for ways to help the memory retain and recollect the most important things:

The next remedies in this universal cure of the Mind are to be applyed to the Memory, and they are to consist of such Directions as may inform us, what things are best to be stor'd up for our purpose, and which is the best way of so disposing them, that they may not only be kept in safety, but ready and convenient, to be at any time produce'd for use, as occasion shall require. (Hooke 1665, "Preface," sig. b1v)

Read out of context this passage might seem to be another attempt to improve individual memory; but seen as part of Hooke's mission of "rectifying the operations of the Sense, the Memory, and Reason" it was more than this (Hooke 1665, "Preface," sig. a1r). Hooke realized that for the effective management of large amounts of information (as expected in Baconian science) individual memory had to be orchestrated by social and institutional conventions. In this way, memory could contribute to, and rely on, an external repository. Thus the start of the Micrographia certainly invites comparisons with Bush's dream of individuals, aided by devices such as cameras fitted to spectacles, recording all the data of their experience and storing this in their personal memex. However, in his "General Scheme" (c.1666), Hooke concluded that the external storage of information has to be governed by collective, rather than individual, interests and that these might include shared categories and principles of classification. ${ }^{26}$ I return to this below.

\section{John Locke: the Limits of Memory}

In Locke's Essay there are some important passages on augmented faculties, including memory, which can be understood as responses to Hooke's comments in the Micrographia. Locke cautions against cyborg fantasies as solutions to man's fallen condition in this "state of mediocrity" (Locke [1690] 1975, IV.xiv.2). We don't have perfect vision or hearing, and certainly not perfect memory. Our state of probation is one that we have to endure, even though it is legitimate to seek some improvements.

\footnotetext{
${ }^{26}$ In the Micrographia, he alludes to "another Discourse" (Hooke 1665, "Preface," sig. b1v), which must be "A General Scheme," probably written in about 1666, and published posthumously (Hooke 1705a).
} 
However, Locke does not expect any enhancements of the senses to give access to the inner nature of things. Such knowledge was not part of God's plan:

The infinite wise Contriver of us, and all things about us, hath fitted our Senses, Faculties, and Organs, to the conveniences of Life, and the Business we have to do here. We are able, by our Senses, to know, and distinguish things... But it appears not, that God intended, we should have a perfect, clear, and adequate Knowledge of them. (Ibid., II.xxiii.12)

Locke indulges in some virtuoso thought experiments about enhanced human faculties. His contention is that these improvements would not be adaptive in this world: "If our sense of Hearing were but 1000 times quicker than it is, how would a perpetual noise distract us. And we should in the quietest Retirement, be less able to sleep or meditate, than in the middle of a Sea-fight" (ibid.). Touching closely on Hooke's project, he then considers "that most instructive of our Senses, Seeing." Locke does seem to concede that if a person's vision were a 100 or 1000 times more acute than the "best Microscope" then he would "come nearer the Discovery of the Texture and the Motion of the minute Parts of corporeal things." However, a man with "Microscopical Eyes" would also be ill-suited to this world: he "would be in a quite different World from other People: Nothing would appear the same to him, and others ... So that I doubt, Whether he, and the rest of Men, could discourse concerning the Objects of Sight" (ibid.). ${ }^{27}$

How does memory fit into this argument? The short answer is that even if our senses were perfect and capable of penetrating to the "real essences" of things, our weak memories would not be able to retain and use the richer data. I think Locke regards the prospect of perfect memory as a more complex case than that of perfect senses. It is not clear whether he believes that the possession of perfect hearing or vision would alter our ontological status, although he certainly says that both would be non-functional capacities in this world. However, perfect sight, for Locke, is still sight, perhaps akin to Adam's vision; but perfect memory bears no relation to human memory. Locke stresses that forgetting is a central fact of the human condition. Indeed, he incorporates the weakness of memory into his account of how language works: names for general concepts allow us to forget particulars that would quickly tax the memory. As Locke explains, "general Notions," to which we attach abstract names, allow us to "disburden the Memory of the cumbersome load of Particulars" (ibid., IV.xii.3; see Borges 1964, 93 for a reference to Locke).

In Locke's view, human knowledge would be restricted even if our five senses were perfect, or artificially extended - because of the limits of memory. However, his starting point is that memory is a crucial faculty: without it we could not build up knowledge

\footnotetext{
${ }^{27}$ Locke insists that even if we could extend our senses we could not achieve knowledge of "real essences" (see Locke [1690] 1975, III.vi.1-3; also II.xxiii.4). On his caveats about the microscope in this regard, see Alexander 1985, 184-7, 296; Wilson 1995, 238-43.
} 
from sensations and ideas, by compounding and reflection. In short, "Memory, in an intellectual Creature, is necessary in the next degree to Perception. It is of so great moment, that where it is wanting, all the rest of our Faculties are in a great measure useless" (ibid., II.x.8). ${ }^{28}$ And yet memory is imperfect. Locke catalogues its weaknesses, such as slowness in retrieval and decay over time. The ideas we do at various times perceive and entertain soon fade and can be lost entirely; some, like the "Children, of our Youth," are lost before we die (Locke 1975, II.x.4-5). As Locke reflects, "it would be well with us, if our Knowledge were but as large as our Ideas." However, our memories cannot reliably recall and compare the number of ideas that pass through our minds. These are the grounds on which he declares "the extent of our Knowledge comes not only short of the reality of Things, but even of the extent of our own Ideas" (ibid., IV.iii.6; emphasis in original).

Locke underlines this fragile capacity of memory as a way of distinguishing ontologically between humans and other superior intellectual beings, such as angels. In fact, he regards memory as required only because of the limits of human mental capacity: "For the narrow Mind of Man, not being capable of having many Ideas under View and Consideration at once, it was necessary to have a Repository, to lay up those Ideas, which at another time it might have use of" (ibid., II.x.2). He calls memory "the Store-house of our Ideas," thus adopting a metaphor from the art of memory, although in his account this storehouse runs a poor second to what it might have been (ibid., II.x.2; also II.xxxii.7). Locke's point of comparison is the capacity of "some superiour created intellectual Beings" whose minds can hold "constantly in view the whole Scene of all their former actions, wherein no one of the thoughts they have ever had, may slip out of their sight" (ibid., II.x.9). It is not merely that such minds have the ability to "see and know the Nature and Inward Constitution of things"; rather, it is that they also have "a larger Comprehension, which enables them at one Glance to see the Connexion and Agreement of very many Ideas, and readily supplys to them the intermediate Proofs, which we by single and slow Steps ... hardly at last find out, and are often ready to forget one before we have hunted out another" (ibid., IV.iii.6; see also Yolton 2004). In other words, angels do not need memory; we do, but it often fails us. ${ }^{29}$

\section{Memory and Archives}

One result of this theological and philosophical speculation about the limits of memory is that Hooke and Locke both came to accept the need for reliance on external

\footnotetext{
${ }^{28}$ For other notices of the crucial role of memory in knowledge, see Locke [1690] 1975, IV.i.8-9; IV.xi.11.

${ }^{29}$ Locke admits that there are examples of extraordinary memory among mortals and gives the case of the French mathematician, Blaise Pascal, reciting the claim of Pascal's sister that until the decline of his health her brother "forgot nothing of what he had done, read, or thought in any part of his rational Age" (Locke [1690] 1975, II.x.9). But Locke decides that Pascal was blessed with a gifted natural memory, not an artificially enhanced one. Locke added this passage to the chapter "Of Retention" in the second edition of the Essay (Locke 1694, 72-3).
} 
archives of information. With many of their contemporaries, they believed that the classical art of memory was of little use in dealing with the mass of particulars required, for example, in natural history and chemistry. They thought in terms of the postlapsarian situation and asked whether it was possible, and desirable, to enhance our senses, and memory. Locke said no to all of this; Hooke said yes, and risked his health by imbibing various substances. Both also decided that improved memory was not the simple equivalent of augmented vision and hearing. Memory stored and revived ideas gathered by the five senses, and it supplied ideas to Reason. But since memory was obviously unreliable, human understanding and knowledge would be fatally compromised without corrective measures. My key point in this section is that Hooke and Locke both distrusted the temporal and associative character of memory and concluded that external storage and retrieval processes must break with such patterns. As mentioned earlier, it is Bush who wanted to preserve these patterns in his memex. Some further background is necessary here.

When Thomas Hobbes sought to explain a "Trayne of Thoughts" in the mind he alluded to the associative character of memory (Hobbes [1651] 1996, 20). He gave this example: "from St. Andrew the mind runneth to St. Peter, because their names are read together; from St. Peter to a stone, because we see them together; and for the same cause, from foundation to church, from church to people, and from people to tumult." Hobbes did not claim that this sequence was "casual and incoherent, as in dreams for the most part," but rather that its coherence, or the connection between one idea and the next, was determined by a link made "at that time when they were [first] produced by the sense." He reasoned that "according to this example, the mind may run almost from any thing to any thing" (Hobbes [1650] 1928, 10-11). ${ }^{30} \mathrm{We}$ need to add here that according to René Descartes' trace theory of memory (known to Hobbes, Hooke, and Locke), such paths will be laid down in the porous matter of the brain and followed again and again (Sutton 1998; Gaukroger 2002, 204-6; Clarke 2003, 93-105).

In his De Memoria et Reminiscentia, Aristotle distinguished between remembering and recollection (reminiscentia) - the latter being a deliberate search for something stored in memory (Sorabji 1972, 52-60). Aquinas used Aristotle's distinction to classify recollection (including artificial memory) as a rational capacity and natural memory as belonging to the sensitive part of the soul, and therefore subject to the effects of bodily humours, such as choler (or bile) - the basis of a melancholic disposition (Yates 1966, 76-92; Carruthers 1990, 61-70). The early modern thinkers I discuss here also made this distinction, but they did not regard the task of recollection as being substantially aided by mnemonic rules which, they contended, were additional burdens on natural memory. Furthermore, they warned that the trains of association, such as those described by Hobbes, might easily skew any deliberative chain of recollection.

\footnotetext{
${ }^{30}$ William James cited the passage from Leviathan on train of thoughts, and gave his own account of both retention and recollection in terms of "habit-worn paths of association" (James 1890, I: 655).
} 
Locke was especially concerned by this. Even before the chapter "Of the Association of Ideas" was added to the fourth edition of the Essay (1700), he displayed anxiety about disorderly habits of mind. In Of the Conduct of the Understanding (begun in 1697), at one point intended as a chapter of the Essay, ${ }^{31}$ he gave examples of how the "association of ideas" could produce "unnatural connexions," usually peculiar to the individual. Indeed, the influence of custom, or "the empire of habit," produced "a disease of the mind as hard to be cured as any" (Locke [1823] 1963, 276, 283-84). In the Essay, Locke separated this erroneous association from the "natural correspondence and connexion" of ideas that reflect real unions in the world that reason must seek to discover. When he spoke of the "association of ideas," Locke referred to "the wrong connexion in our minds of ideas in themselves, loose and independent one of another" (Locke [1690] 1975, II.xxxiii.4 and 9; also II.xi.13). On this basis, he diagnosed the associative character of memory as a barrier to clear analysis and novel connections. Of course, reason and judgment needed access to ideas held in memory; the strategy, therefore, especially for the new sciences, was to externalize data for the purposes of resorting, comparison, and generalization. ${ }^{32}$ Locke's recommendations about the use of commonplace books can be seen in this context. ${ }^{33}$

Hooke reached a similar conclusion. Although attracted by the promise of enhancing individual memory, he gave more prominence to the needs of "Reason," or "the Understanding," in his methodological stipulations. To some extent, this direction was foreshadowed in the Micrographia where he called for a thoroughgoing reform of all human senses and faculties, because "the whole chain is in danger of being dissolv'd; it is to begin with the Hands and Eyes, and to proceed on through the Memory, to be continued by the Reason" (Hooke 1665, "Preface," sig. b2r). He also indicated that this reform should move beyond individual memory so that reason had a collective memory at its disposal: "What ought to be thought of that man, that has not only a perfect register of his own experience, but is grown old with the experience of many hundreds of years, and many thousands of men" (Hooke 1665, "Preface," sig. d1r). In the "General Scheme," he concentrated on the methods of storing, arranging, and analyzing this information (Hooke 1705a). ${ }^{34}$ Expressing his debt to Bacon, Hooke stressed the collaborative aspects of scientific inquiry and admitted that the capacities of individuals, however strong, were not sufficient:

\footnotetext{
${ }^{31}$ For Locke's note that "Of the Conduct of the Understanding" would be chap. 20 in Book IV, see MS Locke e.1, p. 62, Bodleian Library, Oxford; and Locke to William Molyneux, 26 April 1695, in Locke 1976-1989, vol. 5: letter no. 1887.

${ }^{32}$ Descartes made a similar point in his Regulae ad Directionem Ingenii (c. 1619-28), rule 7 (see Descartes [1701] 1985, 25). A Dutch translation appeared in 1684, and the first Latin translation in 1701 (see Gaukroger 1995, 111-15, 434). It is unlikely that either Hooke or Locke had access to the manuscript prior to publication.

33 There is no space to treat this here, but see Yeo 2004.

${ }^{34}$ For Hooke's note-taking in this context, see Mulligan 1992a; Yeo 2007.
} 
For where the Examination and Comparison of so great a Number of Particulars is requisite, and where the Process is long, and the Informations but thinly scatter'd, and those also in the Dark, 'tis not to be expected from the most subtile Wit, that the whole Operation should be only performed by the Strength of its Memory, and the Activity of its Ratiocination, though each of them in the greatest pitch of Perfection. (Ibid., 5)

In any case, at the individual level, memory and reason were often unequally represented - as epitomized, Hooke noted, in the proverb that "good Wits have ill Memories" (ibid.). In collective inquiries, the capacities of individuals had to be marshaled in a methodical fashion for the good of science. Here he made memory subordinate to reason:

... the Ratiocination is helped first, by being left alone and undisturbed to it self, having all the Intention of the Mind bent wholly to its Work, without being any other ways at the same time imployed in the Drudgery and Slavery of the Memory, either in calling particular things to Memory, or ranging them in Order, or remembring such things as belong to another Head, or in transposing, jumbling, ranging, methodizing, and the like. (Ibid., 34)

The importance of ensuring that reason was not constrained by memory was, I suggest, reinforced by Hooke's own theory of the physical workings of memory outlined about fifteen years later in his "Lectures of Light." In the seventh of these lectures, he suggested that the memory receives ideas in temporal order, linked to one another and so forming a "Chain of Ideas coyled up in the Repository of the Brain, the first end of which is farthest removed from the Center or Seat of the Soul where the Ideas are formed; and the other End is always at the Center, being the last Idea formed" (Hooke 1705b, 140). ${ }^{35}$ Each idea carries its content and a marker of its position in the chain, "disposed in some regular Order; which Order I conceive to be principally that according to which they are formed" (ibid.). ${ }^{36}$ However, scientific inquiry into the patterns and laws of the natural world demanded an ability to reorder this temporal chain of ideas for analysis. I think that M. M. Slaughter overlooks this disparity when she says that "in his treatise 'On Memory' ... he [Hooke] discusses the formation of ideas noting that these dispose themselves in an order such that there is a continued chain of ideas in the brain. This mental ordering of elements presumably matches the ordering of nature" (Slaughter 1982, 183). But Hooke believed that this was not the case: the chain of ideas in memory was laid down in chronological order; it did not mirror the true patterns in nature. When lamenting the various weaknesses

\footnotetext{
${ }^{35}$ Hooke used this notion to explain our sense of temporal duration. On Hooke's weather clock as an analogue of memory in this respect, see Wilding 2006, 124.

${ }^{36}$ Hooke thought of memories as discretely localized; whereas Descartes possibly allowed for superimposition and distribution throughout the brain (see Sutton 1998, 134-5,137-8, 151-2). Hooke was therefore less worried about what Glanvill called "a disorderly floating” or "Chaos of confusion” (Glanvill 1661, 36-89).
} 
of memory, he was not merely worried about the tendency to forget; in addition, as he put it, the memory "cannot so well propound all it does remember, to be examin'd at once by the Judgment; but prefers some things first in order, before others, and some things with more Vehemence and greater concern" (Hooke 1705a, 6). ${ }^{37}$ On this basis, he concluded that the natural processes of memory could not provide a sound basis for the work of reason. What was to be done?

Hooke used the word "Repository" to describe both individual memory and the collection of papers and objects owned by the Royal Society. His method of collective inquiry called for this storehouse to be conceived as an externalized memory of material able to be analyzed and re-arranged by reason. In this way, scientific analysis would transcend the temporal or associative patterns of natural memory. This project required a generally agreed set of categories under which information could be gathered and stored. In his role as Curator of the Royal Society's Repository, Hooke used the taxonomy in John Wilkins' Essay Towards a Real Character, and a Philosophical Language (1668). Thomas Sprat reported on this in his History of the Royal Society (1667): "This Repository he [Hooke] has begun to reduce under its several heads, according to the exact Method of the Ranks of all the Species of Nature, which has been compos'd by Doctor Wilkins, and will shortly be published in his Universal Language" (Sprat [1667] 1959, 251). Wilkins was not merely seeking a lingua franca to replace Latin, nor was he hoping to recover the lost pristine language of Adam. The crucial point was that the symbols of his universal character reflected a general classification of both "Notions" and "Things." 38 Wilkins proposed "40 common Heads or Genus's" and, following Aristotle, subdivided these into "Differences" and "Species." Symbols or words (respectively, for the written and spoken versions) were allocated on the basis of this framework. These then not only denoted a notion or a thing, but also the place of the referent in the wider classification. For example, in the spoken version, the word "Zana" combines "Za" (the genus fish); " $n$ " indicating "squamous river fish," the ninth "Difference"; and "a," pinpointing the second species, the salmon "of a reddish flesh" (Wilkins 1668, 142). ${ }^{39}$ Wilkins explained the advantages of this method: "But now if these Marks or Notes could be so contrived, as to have such a dependance upon, and relation to, one another, as might be suitable to the nature of things and notions which they represented... and we should, by learning the Character and Names of

\footnotetext{
${ }^{37}$ I take this to indicate that, in addition to the problem of the order of recollection, there were also biases produced by individual interests and passions - although as far as I can tell Hooke did not use the term "association" in this context.

${ }^{38}$ The scholarship on universal languages is considerable (see, for example, Aarsleff 1970-90, 361-81; Knowlson 1975; Salmon 1988; Rossi 2000; Maat 2004). The best account of the connection with the sciences is Slaughter 1982.

${ }^{39}$ For the taxonomy of the plant and animal kingdoms, Wilkins relied on John Ray and Francis Willughby (see DeMott 1957, 3-12; Slaughter 1982, 62-3, 184-6). Nehemiah Grew, who catalogued the Royal Society collection, agreed with Wilkins' approach to classification: "So that the Names of Things should always be taken from something more observably declarative of their Form, or Nature" (Grew 1681, "Preface," sig. A32v).
} 
things, be instructed likewise in their Natures, the knowledg of both which ought to be conjoyned" (ibid., 21). ${ }^{40}$ In turn, he argued that once the systematic ordering of the main categories was grasped, this would "much facilitate the fixing of them in the memory" (ibid., 441).

As Slaughter has suggested, it is quite feasible that Hooke's ideas about how to build and organize a scientific repository were indebted to Wilkins' scheme (Slaughter 1982, 159). The nomenclature of this universal character, based on a fixed classification of the world, allowed mnemonic possibilities. ${ }^{41}$ Such a taxonomy offered one way of both guiding the collection of information and arranging it. The many references in the "General Scheme" to natural order resonate with this, as does Hooke's undelivered promise of a "Philosophical Algebra" that would act as an aid to both memory and thinking in all "Natural Inquiry" (see Hesse 1966; Mulligan 1992b). He also suggested the use of symbols and shorthand as a way of saving time, space, and pressure on memory; the result, he said, might "not improperly be call'd a Philosophical Algebra, or an Art of directing the Mind in the search after Philosophical Truths" (Hooke 1705a, 6-7). ${ }^{42}$ Of course, these symbols (as in Wilkins' scheme) required the prior establishment of fundamental categories. Here there was a need to pause. Although Hooke sketched out "Heads of Inquiry" for the compilation of fifty-six natural histories, he acknowledged that these Heads might need revision as further "Observations and Experiments" superseded earlier material. He proposed keeping a large book into which slips of "very fine Paper" could be inserted; this would facilitate the process of continual sifting and reshuffling, which could not be accomplished by memory. Thus data could be moved around so that information "which was plac'd first may be plac'd middle-most, or last, or transpos'd to another Head” (ibid., 64).

We might say that Hooke envisaged a large collective memex. However, Hooke's thinking conflicted with the assumptions underlying Bush's proposal in at least two fundamental respects: he stressed the importance of shared classification; and he saw this as a protection against both the rigid and the idiosyncratic patterns of natural memory.

\footnotetext{
${ }^{40}$ Locke was not confident that our knowledge of universals was sufficiently secure to ground a general classification. He attacked universal languages in the Essay (Locke [1690] 1975, III.xi.2). However, when asked by his friend, Nicolas Toinard, about George Dalgarno's, Ars Signorum (1661), Locke recommended that he look at "le livre du Dr Wilkins le seu Evesque de Chester qu il a ecrit in folio en Anglois de Charactere universali..." (see Locke to Nicolas Toinard, 30 August 1681, in Locke 1976-1989, vol. 2, letter no. 656).

${ }^{41}$ Wilkins was Hooke's mentor at Oxford, and Hooke's abiding interest in artificial languages is well documented (see, for example, Hooke 1726, 142-50; Hooke 1686; and Hooke 1968 for many diary entries between 1673 and 1680).

${ }^{42}$ In a letter to Leibniz he called this "the Algebra of Algebras or the Science of methods" (see Robert Hooke to G. W. Leibniz, 15 May 1681, Royal Society of London, Letter Book, EL/H3/64. See also Hooke's unpublished "Mathematical Language," Royal Society Classified papers, xx, no. 72, cited in Slaughter 1982, 183). Leibniz was enthusiastic about Wilkins' contribution "towards creating a perfect language for philosophical purposes" but maintained that more could be done to develop the real character into an instrument of thought (see Leibniz to Henry Oldenburg, 13 July 1670 in Oldenburg 1965-86, 7: 67 [trans. from the Latin original by the editors]; also Fontenelle [1818] 1968, 246-7).
} 
As noted earlier, Bush mentioned Leibniz's plans for a calculating machine, but he seemed to divorce this from its connection with the philosopher's attempt to analyze and classify the relationships between primitive ideas as the groundwork of a symbolic logic. ${ }^{43}$ Bush's memex recorded previous searches of an individual mind; in this sense, it registered associations between ideas, but it did not order them by logical or other criteria. In contrast, Hooke's archive incorporated the empirical information supplied by individuals and the categories gradually established by collective effort. Potentially, the existence of such an organized repository might influence the manner in which individuals stored information in memory - namely, under the categories agreed on by a community. But the fact that it was an active repository meant that any reconfiguring of its contents had to be carefully monitored. From what is known of Hooke's attitudes, it is likely that his ideal archive was a controlled one. In this sense, he was thinking of an "institutional" repository, not one open to any "public" (see Feingold 1998; Johns 1998, 475-87; Wilding 2006, 131-33). In contrast, for Bush, the memex was a personal tool entirely under the dominion of its owner - even though an institutional version might well have appealed to corporate and military organizations of his time.

\section{Vannevar Bush: Memory as a Model for Memex}

There are ambiguities in the name Bush gave to the device he described as "an intimate supplement to memory." His biographer says that he "considered the memex a mechanical aid to memory (hence its name)"; and similarly, others have understood this term as a contraction of "memory extended" (Zachary 1997, 262). ${ }^{44}$ However, another interpretation is that memex stands for "memory index": thus mem(ory) (ind)ex (Buckland 1992, 285). I think this latter view is more plausible because Bush attacked conventional indexing: "When data of any sort are placed in storage, they are filed alphabetically or numerically, and information is found (when it is) by tracing it down from subclass to subclass.... Having found one item, moreover, one has to emerge from the system and re-enter on a new path." He then made this contrast: "The human mind does not work that way. It operates by association. With one item in its grasp, it snaps instantly to the next that is suggested by the association of thoughts, in accordance with some intricate web of trails carried by the cells of the brain" (Bush 1945, 106). ${ }^{45}$

In a later version of his article, Bush sketched a more sophisticated "Memex II":

\footnotetext{
${ }^{43}$ For the connection between this attempt and Leibniz's interest in artificial or philosophical languages, see Maat 2004, chap. 5.

${ }^{44}$ See, for example, Rheingold 2000, 175: "Because one of its functions was to extend human memory, Bush called his hypothetical machine a memex."

${ }^{45}$ In a letter of 19 November 1944, Bush wrote: "When items are thus tied together in a chain, when any item in the chain can be caused to be followed by the next, instantly and automatically, wherever it may be, there is formed an associative trail through the material. It is closely analagous [sic] to the trail formed in the cells of the brain, and it may be similarly employed" (cited in Nyce and Kahn 1991, 58; see also Bush 1970, 190-1).
} 
Many years ago I described a machine, called the Memex, which I conceived of as a device that would supplement thought directly rather than at a distance. It abandoned the usual indexing schemes in handling data, and substituted the construction through the data of trails of association which it included in its memory. ... The time has come to it try again ... thanks to the psychologists and the neural physiologists, we have a clearer conception of how the brain actually functions, and hence a better chance of joining it with a machine which can truly supplement because it does things in much the same way. (Nyce and Kahn 1991, 166) ${ }^{46}$

Bush forecast that Memex II (using magnetic tape) would learn and guess on the basis of past commands: "For the machine remembers what it has been caused to do. Thus, when left to itself, stepping along some indicated trail, it will pause and explore a side trail if that has been its experience often when the trail was followed under orders" (ibid., 176). The upgraded memex was better at capitalizing on associative links than the brain which it imitated:

The machine's primary service lies primarily in extending the mass of recollection, and in rendering this explicit rather than vague. It also provides a memory which does not fade, and by causing it to be more promptly accessible than by the somewhat haphazard trails of association in the brain itself.... This, in turn, remolds the trails of the user's brain, ... For the trails of the machine become duplicated in the brain of the user, vaguely as all memory is vague, but with a concomitant emphasis by repetition, creation and discard, refinement, as the cells of the brain become realigned and reconnected, better to utilize the massive explicit memory which is its servant. (Ibid., 177-8). ${ }^{47}$

This final vision reveals a tension in Bush's position. In the original article he distinguished between creative and mechanical processes (including routine mathematical and logical ones), stating that associative thinking was of the former kind. The problem was that although natural memory often recalled by way of such association, these links could fade. The memex preserved trails of such associative connections, thereby allowing its user to find and retrace them. However, in "Memex II," he asserted that the brain (and natural memory) is trained by the memex, or that there is a tight cybernetic bond between them. Since the spontaneity and unpredictability of associations were the features of human thinking and memory that Bush sought to preserve in the memex, it is odd that a repetitive machine almost came to be the master of its user's mind. Another striking consequence is that a memex is a memento, not only of past documentary searches, but of its owner's thought processes:

\footnotetext{
46 This is from the unpublished draft intended as a proposal for "Memex II," 27 August 1959 (MIT Archives MC78, box 21).

${ }^{47}$ Two relevant points which I cannot discuss here are: i) Bush's own preference for analog technology; ii) Norbert Wiener's notion of "servomechanisms" that effaced the distinction between human and machine (see Zachary 1997, 273-6; Nyce and Kahn 1991, 61-4; Galison 1994).
} 
Can a son inherit the memex of his father, or the disciple that of his master, refined and polished over the years, and go on from there? In this way can we avoid some of the loss which comes when oxygen is no longer furnished to the brain of the great thinker? ... Can the race thus develop leaders, of such power of intellect, and such forces of conviction, that the world can be saved from its follies? (Ibid., 183)

\section{Concluding Remarks}

I do not pretend that these snapshots, separated by almost three centuries, can produce convincing generalizations about the changing relations between memory and information. However, despite differences in the sophistication of theories about memory processes and technologies for storage and retrieval of information, they indicate that in such a history there are some ubiquitous issues that can be discussed under the following themes.

\section{Classification and Searching}

We have come to expect that improvements in information technology weaken the connection between classification and retrieval of data. In our digital world, searches by word or letter combination render subject categories almost superfluous. Neither Hooke nor Locke were prepared to go this far, even though they did break with the notion of a standard set of commonplace Heads, as found in both scholastic and humanist pedagogy. Subject or topic headings remained important as a means of grouping empirical particulars; such arrangements could be revised, but not abandoned. In contrast, Bush regarded the classification of information in terms of subject matter, or discipline, or proximity on some map of knowledge as largely irrelevant to effective retrieval. This was despite the fact that users of memex depended initially on general categories to assemble the ingredients of their personal encyclopedias. But once started, the memex allowed individuals to index and locate documents solely in terms of affinity to some theme chosen and named by them. The trail of documents was determined by searches under this theme, irrespective of disciplinary boundaries.

\section{Individual versus Collective Repositories of Information}

Both Hooke and Locke reflected on the use of personal notebooks as a way of managing the amount of information required by scientific research. Hooke, in particular, also discussed the concept of an archive, arranged by agreed categories, acting as an external reference point for the collection of information. In the search for new relationships, this archive could be re-organized more easily than any individual could re-order his or her own memory. There was the possibility that individuals could benefit from such a collective effort, accepting the categories and the patterns that emerged and 
disciplining their own memories accordingly. With this much at stake, permission to reassign material to different categories was likely to be an institutional decision. In contrast, Bush regarded the memex as a personal, even private, device in the battle against information overload - a problem not adequately addressed, in his opinion, by library catalogs. His focus was on personal users who needed to keep track of their own thoughts and information gathered for a special purpose. ${ }^{48}$ By repeating the trails of its owner's previous searches, the memex was a strangely personal machine, forever adding to and retracing old trails, only rarely embarking on new lines of inquiry, and never reorganizing data under different headings, as Hooke demanded.

\section{The Role of Memory in Information Management}

Hooke and Locke lived in a culture in which a strong memory was highly valued despite the waning profile of the classical art of memory. It is not surprising, therefore, that they explored the possibility of improving natural memory. However, when considering how information, especially scientific data, should be stored and organized, they made a radical break with natural memory. They stressed the externalization of information in a manner that attempted to ensure against the fragilities and idiosyncrasies of memory. The surprising fact is that Bush sought to recapitulate the associative patterns of individual memory in the search functions of the memex. Regarding this invention as an analog of memory, he came to see it as reliable retainer of the creative, though often arbitrary, connections made by the mind, so that "there are built up trails of association in the memory, of brain or machine" (Bush 1970, 191). Although all three thinkers began with the perception that the mass of information outstripped the capacity of individual memory, they arrived at different conclusions. Hooke and Locke gave priority to reason and judgment over memory; Bush made natural memory the model for an externalized memory device more powerful than his seventeenth-century predecessors could have imagined.

\section{Acknowledgments}

The research for this article was made possible by an Australian Professorial Fellowship awarded by the Australian Research Council. For access to material in their custody, I am grateful to the Royal Society of London, the British Library, and the Keeper of Modern Western Manuscripts, Bodleian Library, Oxford. I thank the Warden and Fellows of All Souls College, Oxford, for their support while I was a Visiting Fellow

\footnotetext{
${ }^{48}$ Nevertheless, Bush did canvas the possibility of creating a discipline-based memex (see Nyce and Kahn 1991, 173-4). Yet, even later when he reflected on the use of large digital computers in industry, Bush reserved a distinctive role for a personal machine along the lines of memex (see Bush [1967] 1991, 211; for the original version, see Bush 1967, 75-101).
} 
during 2004-5. For helpful comments and suggestions, I am grateful to two anonymous referees and the editors of this journal.

\section{References}

Aarsleff, Hans. 1970-90. "Wilkins." In Dictionary of Scientific Biography, edited by Charles C. Gillispie, 18 vols., 14:361-81. New York: Charles Scribner's Sons. Reprinted in his From Locke to Saussure: Essays on the Study of Language and Intellectual History, 239-277. London: Athlone Press.

Agrippa, Henricus Cornelius. [1531] 1569. Henrie Cornelius Agrippa, Of the Vanitie and Uncertaintie of the Artes and Sciences, Englished by Ja. San. gent. London: Henry Wykes.

Alexander, Peter. 1985. Ideas, Qualities, and Corpuscles: Locke and Boyle on the External World. Cambridge: Cambridge University Press.

Anon. 1945a. "A Machine That Thinks." Time, 23 July, p. 41.

Anon. 1945b. "What Dr. Bush Foresees." Life, 10 September, pp. 112-124.

Anon. 1954. Ad Herennium. De ratione dicendi. With an English Translation by Harry Caplan. Cambridge: Harvard University Press.

Augustine, Saint, Bishop of Hippo. 1961. Confessions. Translated with an introduction by R. S. PineCoffin. Harmondsworth: Penguin.

Bennett, Jim, Michael Cooper, Michael Hunter, and Lisa Jardine. 2003. London's Leonardo: the Life and Work of Robert Hooke. Oxford: Oxford University Press.

Blair, Ann. 2004. "Note Taking as Transmission." Critical Inquiry 31:85-107.

Borges, Louis. 1964. "Funes the Memorius." In Labyrinth, edited by Donald A. Yates and James E. Irby, 87-95. London: Penguin Books.

Buckland, Michael K. 1992. "Emanuel Goldberg, Electronic Document Retrieval, and Vannevar Bush's Memex." Journal of the American Society for Information Science 43:284-291.

Bush, Vannevar. 1945. “As We May Think.” Atlantic Monthly (July):101-108.

Bush, Vannevar. 1946a. Endless Horizons. Washington, D. C.: Public Affairs Press.

Bush, Vannevar. [1933] 1946b. "The Inscrutable Past." In his Endless Horizons, 1-15. Washington, D. C.: Public Affairs Press.

Bush, Vannevar. 1967. Science Is Not Enough. New York: William Morrow.

Bush, Vannevar. 1970. Pieces of the Action. New York: William Morrow.

Bush, Vannevar. [1967] 1991. "Memex Revisited." In From Memex to Hypertext: Vannevar Bush and the Mind's Machine, edited by James M. Nyce, and Paul Kahn, 197-215. Boston: Academic Press.

Carruthers, Mary. 1990. The Book of Memory: a Study of Memory in Medieval Culture. Cambridge: Cambridge University Press.

Clark, Andy. 2003. Natural-Born Cyborgs: Minds, Technologies, and the Future of Human Intelligence. Oxford: Oxford University Press.

Clark, Andy, and David Chalmers. 1998. "The Extended Mind.” Analysis 58(1):7-19.

Clarke, Desmond. 2003. Descartes's Theory of the Mind. Oxford: Clarendon Press.

Clynes, Manfred E., and Nathan S. Kline. 1960. "Cyborgs and Space." Astronautics (September):26-27, $74-75$.

Coleman, Janet. 1992. Ancient and Medieval Memories: Studies in the Reconstruction of the Past. Cambridge: Cambridge University Press.

Dalgarno, George. 1661. Ars Signorum, Vulgo Character Universalis et Lingua Philosophica. London: J. Hayes.

Daston, Lorraine. 2004. "Taking Note(s)." Isis 95:443-448.

DeMott, Benjamin. 1957. "Science versus Mnemonics." Isis 48:3-12.

Dennis, Michael A. 1989. "Graphic Understanding: Instruments and Interpretation in Robert Hooke's Micrographia." Science in Context 3:309-64. 
Descartes, René. [1701] 1985. "Rules for the Direction of the Mind." In The Philosophical Writings of Descartes, 3 vols., translated by John Cottingham, Robert Stoothoff, and Dugald Murdoch, vol. 1, 7-76. Cambridge: Cambridge University Press.

Donald, Merlin. 1991. Origins of the Modern Mind: Three Stages in the Evolution of Culture and Cognition. Cambridge: Harvard University Press.

Draaisma, Douwe. 2000. Metaphors of Memory: a History of Ideas about the Mind. Cambridge: Cambridge University Press.

Feingold, Mordechai. 1998. "Of Records and Grandeur: the Archive of the Royal Society." In Archives of the Scientific Revolution: the Formation and Exchange of Ideas in Seventeenth-century Europe, edited by Michael Hunter, 171-184. Woodbridge: Boydell Press.

Fontenelle, Bernard Le Bovier de. [1818] 1968. "Éloge de M. Leibnitz.” In Oeuvres Complètes, edited by G. B. Depping, 3 vols., vol. 1, 226-252. Geneve: Slatkine Reprints.

Galison, Peter. 1994. "The Ontology of the Enemy: Norbert Wiener and the Cybernetic Vision.” Critical Inquiry 21(1):228-266.

Gaukroger, Stephen. 1995. Descartes: an Intellectual Biography. Oxford: Oxford University Press.

Gaukroger, Stephen. 2002. Descartes' System of Natural Philosophy. Cambridge: Cambridge University Press.

Glanvill, Joseph. 1661. The Vanity of Dogmatizing: or Confidence in Opinions. London: E. C. for H. Eversden.

Goyet, Francis. 1996. Le sublime du lieu commun. L'invention rhétorique dans l'Antiquité et à la Renaissance. Paris: Honoré Champion.

Grew, Nehemiah. 1681. Musaeum Regalis Societatis. Or a Catalogue and Description of the Natural and Artificial Rarities Belonging to the Royal Society. London: W. Rawlins.

Harrison, Peter. 1998. The Bible, Protestantism, and the Rise of Natural Science. Cambridge: Cambridge University Press.

Harrison, Peter. 2002. "Original Sin and the Problem of Knowledge in Early Modern Europe.” Journal of the History of Ideas 63(2):239-259.

Harwood, John T. 1989. "Rhetoric and Graphics in Micrographia." In Robert Hooke: New Studies, edited by Michael Hunter and Simon Schaffer, 119-147. Woodbridge: Boydell Press.

Hayles, N. Katherine. 1999. How We Became Post Human: Virtual Bodies in Cybernetics, Literature and Informatics. Chicago: University of Chicago Press.

Hesse, Mary. 1966. "Hooke's Philosophical Algebra." Isis 57:67-83.

Hobbes, Thomas. [1650] 1928. Human Nature. In The Elements of Law, Natural and Politic, edited by Ferdinand Tönnies. Cambridge: Cambridge University Press.

Hobbes, Thomas. [1651] 1996. Leviathan. Edited by Richard Tuck. Cambridge: Cambridge University Press.

Hooke, Robert. 1665. Micrographia, or, Some Physiological Descriptions of Minute Bodies Made by Magnifying Glasses. London: J. Martyn and J. Allestry.

Hooke, Robert. 1686. "Some Observations, and Conjectures Concerning the Chinese Characters." Philosophical Transactions of the Royal Society of London 16:63-78.

Hooke, Robert. 1705a. "A General Scheme, or Idea of the Present State of Natural Philosophy." In The Posthumous Works of Robert Hooke, edited by Richard Waller, 1-70. London: S. Smith and B. Walford.

Hooke, Robert. 1705b. "Lectures of Light, Explicating its Nature, Properties, and Effects." In The Posthumous Works of Robert Hooke, edited by Richard Waller, 71-148. London: S. Smith and B. Walford.

Hooke, Robert. 1726. "Dr. Hook's Discourse to the Royal Society, May 21, 1684 Shewing a Way How to Communicate One's Mind at Great Distances." In Philosophical Experiments and Observations of the Late Eminent Dr. Robert Hooke, edited by William Derham, 142-150. London: W. and T. Innys.

Hooke, Robert. 1968. The Diary of Robert Hooke 1672-1680. Edited by H. W. Robinson and W. Adams. London: Wykeham Publications.

Inwood, Stephen. 2002. The Man Who Knew Too Much. London: Macmillan.

James, William. 1890. The Principles of Psychology. 2 vols. London: Macmillan. 
Jardine, Lisa. 2003. "Hooke the Man: His Diary and His Health." In London's Leonardo: the Life and Work of Robert Hooke, Jim Bennett, Michael Cooper, Michael Hunter, and Lisa Jardine, 163-206. Oxford: Oxford University Press.

Johns, Adrian. 1998. The Nature of the Book: Print and Knowledge in the Making. Chicago: University of Chicago Press.

Kendrick, Michelle. 2001. "Interactive Technology and the Remediation of the Subject of Writing." Configurations 9:231-251.

Kitzmann, Andreas. 2001. "Pioneer Spirits and the Lure of Technology: Vannevar Bush's Desk, Theodor Nelson's World." Configurations 9:441-459.

Knowlson, James. 1975. Universal Language Schemes in England and France, 1600-1800. Buffalo: University of Toronto Press.

Landow, George, P. 1992. Hypertext: the Convergence of Contemporary Critical Theory and Technology. Baltimore: Johns Hopkins University Press.

Lashley, Karl S. 1960. "In Search of the Engram." In The Neuropsychology of Lashley: Selected Papers of K. S. Lashley, edited by Frank A. Beach, Clifford T. Morgan, and Henry W. Nissen, 478-505. New York: McGraw Hill.

Locke, John. [1690] 1975. An Essay Concerning Human Understanding. Edited by Peter H. Nidditch. Oxford: Clarendon Press.

Locke, John. 1694. An Essay Concerning Human Understanding, 2nd edn. London: A. and J. Churchil.

Locke, John. 1976-1989. The Correspondence of John Locke. Edited by E. S. de Beer, 8 vols. Oxford: Clarendon Press.

Locke, John. [1823] 1963. Of the Conduct of the Understanding. In The Works of John Locke. A New Edition, Corrected, 10 vols., vol. 3, 205-289. Darmstadt: Scientia Verlag Aalen.

Luria, A. R. [Luriya, Aleksandr Romanovich] 1975. The Mind of a Mnemonist: a Little Book about a Vast Memory. Translated by L. Solotaroff. Harmondsworth: Penguin.

Maat, Japp. 2004. Philosophical Languages in the Seventeenth Century: Dalgarno, Wilkins, Leibniz. Dordrecht and Boston: Kluwer Academic Publishers.

Malcolm, Noel. 2004. "Thomas Harrison and his 'Ark of Studies': an Episode in the History of the Organization of Knowledge." The Seventeenth Century 19:196-232.

Menary, Richard, ed. 2006. The Extended Mind. Aldershot and Burlington: Ashgate Publishing.

Moss, Ann. 1996. Printed Commonplace-books and the Structuring of Renaissance Thought. Oxford: Oxford University Press.

Mulligan, Lotte. 1992a. "Robert Hooke’s 'Memoranda': Memory and Natural History.” Annals of Science 49:47-61.

Mulligan, Lotte. 1992b. "Robert Hooke and Certain Knowledge." The Seventeenth Century 7:151-169.

Mulligan, Lotte. 1996. "Self-Scrutiny and the Study of Nature: Robert Hooke's Diary as Natural History." Journal of British Studies 35:311-342.

Nyce, James M., and Paul Kahn, eds. 1991. From Memex to Hypertext: Vannevar Bush and the Mind's Machine. Boston: Academic Press.

Oldenburg, Henry. 1965-86. The Correspondence of Henry Oldenburg. Edited and translated by A. Rupert Hall and Marie Boas Hall, 10 vols. Madison: University of Wisconsin.

Oldroyd, D. R. 1980. "Some Philosophical Scribbles Attributed to Robert Hooke." Notes and Records of the Royal Society of London 35:17-32.

Pickering, Andy. 1995. "Cyborg History and the World War II Regime." Perspectives on Science 3: $1-48$.

Rheingold, Howard. 2000. Tools for Thought: the History and Future of Mind-expanding Technology. Cambridge: Harvard University Press.

Richards, Graham. 1992. Mental Machinery: the Origins and Consequences of Psychological Ideas, Part 1: 1600-1850. London: Athlone Press.

Rossi, Paolo. 2000. Logic and the Art of Memory: The Quest for a Universal Language. Translated by Stephen Clucas. London: Athlone Press. 
Salmon, Vivian. 1988. The Study of Language in 17th-Century England. Amsterdam: Benjamins.

Schacter, Daniel. 1996. Searching for Memory: the Brain, the Mind, and the Past. New York: Basic Books.

Singer, B. R. 1976. "Robert Hooke on Memory, Association and Time Perception." Notes and Records of the Royal Society of London 31:115-31.

Slaughter, Mary. 1982. Universal Languages and Scientific Taxonomy in the Seventeenth Century. Cambridge: Cambridge University Press.

Smith, Edward. 2006. "Hooke and Westminster." In Robert Hooke. Tercentennial Studies, edited by Michael Cooper, and Michael Hunter, 219-232. Aldershot and Burlington: Ashgate Publishing.

Sorabji, Richard, ed. 1972. Aristotle on Memory. London: Duckworth.

Sprat, Thomas. [1667] 1959. History of the Royal Society. Edited by Jackson I. Cope, and Harold Whitmore Jones. London: Routledge and Kegan Paul.

Sutton, John. 1998. Philosophy and Memory Traces: Descartes to Connectionism. Cambridge: Cambridge University Press.

Sutton, John. 2002. "Porous Memory and the Cognitive Life of Things." In Prefiguring Cyberculture: an Intellectual History, edited by Darren Tofts, 130-41. Cambridge, Mass.: MIT Press; Sydney: Power Publications.

Waller, Richard, ed. 1705. The Posthumous Works of Robert Hooke. London: S. Smith and B. Walford.

Wells, H. G. [1938] 1994. "The Brain Organization of the Modern World." In his World Brain, 116-118. London: Adamantine.

Wiener, Norbert. [1948] 1973. Cybernetics, or Control and Communication in the Animal and the Machine, 2nd ed. Cambridge, Mass.: MIT Press.

Wilding, Nick. 2006. "Graphic Technologies.” In Robert Hooke: Tercentennial Studies, edited by Michael Cooper, and Michael Hunter, 123-134. Aldershot and Burlington: Ashgate Publishing.

Wilkins, John. 1668. An Essay Towards a Real Character, and a Philosophical Language. London: S. Gellibrand and J. Martyn.

Wilson, Catherine. 1995. The Invisible World: Early Modern Philosophy and the Invention of the Microscope. Princeton: Princeton University Press.

Yates, Frances. 1966. The Art of Memory. London: Routledge.

Yeo, Richard. 2001. Encyclopaedic Visions: Scientific Dictionaries and Enlightenment Culture. Cambridge: Cambridge University Press.

Yeo, Richard. 2004. "John Locke's 'New Method' of Commonplacing: Managing Memory and Information." Eighteenth-Century Thought 2:1-38.

Yeo, Richard. 2007. "Between Memory and Paperbooks: Baconianism and Natural History in Seventeenth-Century England." History of Science.

Yolton, John. 2004. The Two Intellectual Worlds of John Locke: Man, Person and Spirits in the "Essay." Ithaca and London: Cornell University Press.

Zachary, G. Pascal. 1997. Endless Frontier: Vannevar Bush, Engineer of the American Century. New York: Free Press. 